\title{
A daily measure of job satisfaction in the operating room: investigating its value and viability
}

Follow this and additional works at: https://www.journal.acorn.org.au/jpn

Part of the Health Services Administration Commons, Health Services Research Commons, Perioperative, Operating Room and Surgical Nursing Commons, and the Surgery Commons

(c) (i)

This work is licensed under a Creative Commons Attribution 4.0 License.

\section{Recommended Citation}

James-Scotter, Miriam S.; Jiang, Lixin; Walker, Cameron; and Jacobs, Stephen (2020) "A daily measure of job satisfaction in the operating room: investigating its value and viability," Journal of Perioperative Nursing: Vol. 33 : Iss. 3 , Article 3.

Available at: https://doi.org/10.26550/2209-1092.1082

https://www.journal.acorn.org.au/jpn/vol33/iss3/3

This Article is brought to you for free and open access by Journal of Perioperative Nursing. It has been accepted for inclusion in Journal of Perioperative Nursing by an authorized editor of Journal of Perioperative Nursing. 
A daily measure of job satisfaction in the operating room: investigating its value and viability

\section{Cover Page Footnote}

The authors would like to thank and acknowledge all hospital personnel that contributed and participated in this study. 


\section{Authors}

Miriam James-Scotter

BN (Hons), RN

School of Nursing,

Faculty of Medical and Health Sciences,

The University of Auckland

Dr Lixin Jiang

PhD

Senior lecturer, Industrial and

Organisational Psychology, School of

Psychology, The University of Auckland

Assoc. Prof. Cameron Walker

PhD, MA, MSC

Department of Engineering Science,

The University of Auckland

Dr Stephen Jacobs

PhD, BA

Senior lecturer, School of Nursing,

The University of Auckland

\section{Corresponding author}

Miriam James-Scotter

BN (Hons), RN

School of Nursing,

The University of Auckland

m.james-scotter@auckland.ac.nz

\title{
A daily measure of job satisfaction in the operating room - investigating its value and viability
}

\begin{abstract}
Objectives: This study aims to explore the value, validity and viability of implementing a daily job satisfaction tool in the operating room (OR) setting.

Sample and setting: A daily one-minute survey was developed and trialled with 269 OR staff members (123 nurses) over a three-week period in one New Zealand hospital.

Method: A feedback and validation survey was then administered to staff one week following the trial.

Results: The trial resulted in 569 tool submissions. A daily average of 71 per cent of participants (69\% nurses) reported feeling 'pretty good' or 'great' about their jobs, with 'relationships and communication with colleagues' most influential for both a positive and negative day at work. Findings also supported the validity of the tool and highlighted strengths and areas for improvement.
\end{abstract}

Conclusion: The results of the study provide initial support for the value and feasibility of implementing a daily job satisfaction measurement tool in the OR setting. A daily satisfaction measure has the potential to be a powerful tool for perioperative nursing managers at all levels enabling active measurement and management of nurse job satisfaction from an interprofessional perspective.

\section{Introduction}

The association between job satisfaction and burnout, organisational commitment, safety attitudes, the provision of suboptimal care and reduced patient satisfaction has been repeatedly demonstrated for health care employees $^{1-8}$. Clear correlations between job satisfaction and staff turnover, absenteeism and intention to leave are also well recognised ${ }^{8,9}$. Such findings are very relevant at a time when there is increased concern about retention of both nurses and physicians ${ }^{10}$. Consequently, awareness of how staff are feeling about their jobs is a key priority for operating room (OR) managers.
Common performance measures in the OR relate to surgical volumes, theatre utilisation, durations, turnover and financial incoming and outgoings ${ }^{11}$. Over recent years, an increased focus on decreasing burnout has resulted in greater emphasis on improving staff satisfaction in the $\mathrm{OR}^{4,12}$. The subjective nature of job satisfaction, however, makes it difficult to quantifiably and validly measure. Large multi-facet survey methods, traditionally used in the health care setting, often incur low response rates and a high risk of sampling bias. In addition, surveys tend to be conducted infrequently, resulting in outdated information being used by management ${ }^{13,14}$. 
While more frequent measurement is increasing in popularity in the business sector ${ }^{15,16}$, few studies to date appear to have explored realtime measures in the hospital setting with only two hospital studies, that we are aware of, trialling similar tools with hospital employees. Hinsley et al.7 conducted a study in a cardiac catheterisation lab and cardiovascular operating room of one hospital in the United States of America that had a workforce of 51 employees. This study developed and trialled a daily survey which aimed to provide a user-friendly platform to communicate perceptions of the health of the work environment. The survey was offered in both paper and digital form and employees could choose if they wanted to remain anonymous. Similarly, Frampton et al. ${ }^{18}$ conducted a study across 23 different hospital specialty areas in a tertiary teaching hospital in the United Kingdom. They developed and trialled a daily anonymous survey accessed via iPad at multiple kiosks around the hospital. This tool aimed to measure the 'mood' of staff and also provided a broad platform for positive and negative issues to be discussed. These studies will be discussed later in the paper.

\section{Measuring job satisfaction}

While job satisfaction can be defined and interpreted in various ways, it is most commonly defined as the extent to which an individual likes or dislikes their job ${ }^{19}$. Many researchers agree that job satisfaction is made up of a combination of dispositional (relating to personality), cognitive (relating to beliefs) and affective (relating to emotions) components ${ }^{20}$. To date, there is no gold standard as to how job satisfaction should be measured. While there are a number of well-established multifacet questionnaires, the use of singleitem measures to evaluate global job satisfaction has also been supported by numerous well-recognised studies $^{21-23}$.

\section{Objectives}

The objectives of this study were:

1. to develop and trial a daily job satisfaction measurement tool specifically for the OR setting

2. to explore issues relating to the implementation of the tool, with a focus on utilisation, practicality and acceptability

3. to test the tool's convergent validity between daily job satisfaction and overall job satisfaction, and predictive validity of daily job satisfaction with affective commitment (a key component of organisational commitment) and emotional exhaustion (a key component of burnout).

This paper includes the main findings of the study with a particular focus on the OR nurses.

\section{Method}

This study was initiated by senior management in a New Zealand OR setting and was conducted within one New Zealand hospital's operating room department. A multimethod design was adopted, comprising three phases - a development phase, a trial phase and an evaluation phase.

\section{The development phase}

A single-item job satisfaction measurement tool (the 'moraleo-meter') was developed in collaboration with senior management personnel from the OR department at the hospital and with guidance from current literature, an organisational psychologist and a Māori cultural advisor from the hospital (appropriate for the New Zealand context). Once an initial digital version of the tool was developed a short pre-test was conducted within two operating theatres for one day. Participants were invited to test the tool (via iPad) while the first author was present to observe their entries and gather written or verbal feedback relating to their experience of using the tool. Sixteen entries were received leading to numerous modifications of the tool. These changes related to ease of use, comprehensibility and wording as well as technical and reporting requirements.

The morale-o-meter survey was based on a previously validated single-item global measure of job satisfaction used by Dolbier et al. ${ }^{22}$ and Warr, Cook and Wall ${ }^{24}$. It asked 'Overall, how are you feeling about your job today?' The traditional Likert response scale was modified into more casual language, to support 'buy in' from staff, while maintaining an anchored five-point Likert scale ${ }^{25}$. In order to provide meaningful information for managers to understand the reasons behind the responses, the survey then asked employees 'What does this mostly relate to?'. The options for this were derived from the existing literature ${ }^{26,27}$. The survey asked for job role and specialty, and for participants to create a username which they would put in on every use. A guide was provided to prevent people from forgetting their usernames and to ensure anonymity ${ }^{28}$. The moraleo-meter took approximately one minute to complete. See Figure 1 for an outline of the morale-o-meter tool.

\section{The trial phase}

A three-week trial of the moraleo-meter tool was conducted from the 27 May 2019 to 14 June 2019. All employees working in the OR were invited to participate. Seventeen iPads were placed in desk stands 


\begin{tabular}{|c|c|c|}
\hline Question & \multicolumn{2}{|l|}{ Prompt } \\
\hline Username & \multicolumn{2}{|c|}{$\begin{array}{l}\text { The day of the month of your birthday combined with } \\
\text { the first three letters of your mother's name (e.g. 03Jen). }\end{array}$} \\
\hline Time of shift & \multicolumn{2}{|l|}{$\begin{array}{l}\text { - beginning } \\
\text { - middle } \\
\text { - end }\end{array}$} \\
\hline Job site & \multicolumn{2}{|c|}{$\begin{array}{l}\text { (Options were provided but are not identified here to } \\
\text { preserve participant anonymity.) }\end{array}$} \\
\hline $\begin{array}{l}\text { Overall, how } \\
\text { are you feeling } \\
\text { about your job } \\
\text { today? }\end{array}$ & \multicolumn{2}{|c|}{$\begin{array}{l}\text { 1. 'Great, I love my job today!' } \\
\text { 2. 'Pretty good really' } \\
\text { 3. 'Neutral, ho hum...' } \\
\text { 4. 'Not great, actually' } \\
\text { 5. 'Awful, get me out of here!' }\end{array}$} \\
\hline $\begin{array}{l}\text { What does this } \\
\text { mostly relate to? }\end{array}$ & \multicolumn{2}{|c|}{$\begin{array}{l}\text { 1. the nature of the clinical work } \\
\text { 2. communication and relationships with colleagues } \\
\text { 3. organisational factors (e.g. staffing, workload, } \\
\text { resources) } \\
\text { 4. patient interactions } \\
\text { 5. ethnic or cultural wellbeing } \\
\text { 6. other (with open text option) } \\
\text { 7. I'd rather not say }\end{array}$} \\
\hline Job role & $\begin{array}{l}\text { - } \text { - anaesthetist } \\
\text { - } \text { registrar / fellow } \\
\text { - } \text { anaesthetic technician } \\
\text { anaesthetic technician } \\
\text { - } \text { heainee } \\
\text { - nurse }\end{array}$ & $\begin{array}{l}\text { - orderly } \\
\text { - senior nurse } \\
\text { - surgeon } \\
\text { - surgical registrar / fellow } \\
\text { - other } \\
\text { - I'd rather not say }\end{array}$ \\
\hline Speciality & $\begin{array}{l}\text { - } \text { general surgery } \\
\text { - gynaecology } \\
\text { - obstetrics } \\
\text { - ORL } \\
\text { - } \text { orthopaedics }\end{array}$ & $\begin{array}{l}\text { - urology } \\
\text { - other } \\
\text { - not applicable } \\
\text { - I'd rather not say }\end{array}$ \\
\hline
\end{tabular}

Figure 1: Overview of the morale-o-meter tool

across fourteen operating theatres, two tearooms and an anaesthetic technician room. A cell phone option was also made available. The iPad stand displayed instructions asking staff to use the tool once each shift. Recruitment was done via a number of methods: a bulk email invitation was sent to all staff, posters were put up requesting staff participation, and the first author presented at a range age and ethnicity). It used singleitems where possible to encourage completion. It included the following multichoice questions:

- What do you think about having a tool like this in place permanently?

- What device did you prefer to use during the trial?

- What were the barriers to using the tool every shift?

The survey also included an open text section for feedback, comments or suggestions.

The validation question for overall job satisfaction was a well-known single-item global satisfaction question originating from Scarpello and Campbell29: 'All things considered, how satisfied are you in your job?' using a 1 (very satisfied) to 5 (very dissatisfied) response scale.

Affective commitment was measured using a single item selected from the subscale of the organisational commitment scale ${ }^{30}$ : 'I would be happy to spend the rest of my career with this organisation'. Emotional exhaustion was measured using three items derived from the Maslach Burnout Inventory $y^{31}$ : 'I feel used up at the end of the workday', 'I feel emotionally drained from my work' and 'I feel burned out from my work.' The response scales for affective commitment and emotional exhaustion were rated from 1 (strongly agree) to 5 (strongly disagree). Internal consistency reliability of emotional exhaustion was 0.80 .

\section{Data analysis}

Data analyses, including descriptive statistics and pairwise correlations, were completed using SPSS and R statistical software, while multilevel modelling was conducted with Mplus 7.032. Multi-level modelling was considered appropriate for the data analysis due to the non- 
Table 1: Tool participant job roles

\begin{tabular}{|l|c|c|}
\hline Job role & $\begin{array}{c}\text { Number of } \\
\text { participants }\end{array}$ & Percentage \\
\hline Nurses & $\begin{array}{c}123 \\
\text { (20 senior nurses) }\end{array}$ & 45.7 \\
\hline Anaesthetic technicians & 41 & 15.2 \\
\hline Anaesthetists & 19 & 7.1 \\
\hline Surgeons & 18 & 6.7 \\
\hline Surgical registrars / fellows & 18 & 6.7 \\
\hline I'd rather not say & 18 & 6.7 \\
\hline Anaesthetist registrar / fellow & 12 & 2.6 \\
\hline Orderlies & 7 & 2.6 \\
\hline Other & 7 & 0.7 \\
\hline Anaesthetic technician trainee & 2 & 1.5 \\
\hline Health care assistants (HCAs) & $\mathbf{4}$ & $\mathbf{1 0 0}$ \\
\hline Total & $\mathbf{2 6 9}$ & $\mathbf{4}$ \\
\hline
\end{tabular}

Table 2: Tool submissions by specialty

\begin{tabular}{|l|c|c|}
\hline Speciality & $\begin{array}{c}\text { Number of } \\
\text { responses }\end{array}$ & Percentage \\
\hline General surgery & 251 & 44 \\
\hline Orthopaedics & 147 & 26 \\
\hline Gynaecology & 48 & 5 \\
\hline Otorhinolaryngology & 27 & 4 \\
\hline Urology & 23 & 3 \\
\hline Obstetrics & 19 & 7 \\
\hline Not applicable & 38 & $\mathbf{1 0 0}$ \\
\hline I'd rather not say & 16 & $\mathbf{5 6 9}$ \\
\hline Total responses & & 3 \\
\hline
\end{tabular}

independence in the daily-level data where the daily job satisfaction (level 1) responses were nested within individuals (level 2) ${ }^{33}$. specialities participated in the trial, with the largest group being nurses (45.7\%; see Tables 1 and 2). The daily utilisation response rate was approximately 21 per cent ranging from four to 55 entries per day (including weekends and one public holiday). Individual tool utilisation per participant ranged from one to 14 entries (62\% used the tool once, 23\% used the tool two or three times and $15 \%$ used the tool four or more times). Of the total 569 entries, 39 per cent were completed in the middle of the shift, 32 per cent at the end and 29 per cent at the beginning of their shift. No significant relationship was found between the time of the shift when the tool was completed and the level of job satisfaction. For example, participants were not more likely to report a more positive or negative response at the beginning than at the end of their shift.

\section{Tool results}

The job satisfaction response scale was converted to a numerical five-point scale for analysis, i.e. 'Great, I love my job today!' = 1, to 'Awful, get me out of here' $=5$. On average, 71 per cent (range 52-79\%) of total participants reported a 1 or 2 each day (see Figure 2 for daily breakdown). The mean daily satisfaction score was 2.3 (average daily median 2, range $2-2.8$ ). Specific job roles or department specialties did not make a difference in job satisfaction when comparing job satisfaction mean scores. However, we found that participants who chose the option of 'I'd rather not say' for their job role and speciality were more likely to have a lower mean score of job satisfaction compared to the rest of the participants (see Figure 3). A total of 127 nurses and health care assistants participated in the trial, with a daily average of 69 per cent who reported a job satisfaction score of 1 or 2 on an average workday. There was no 


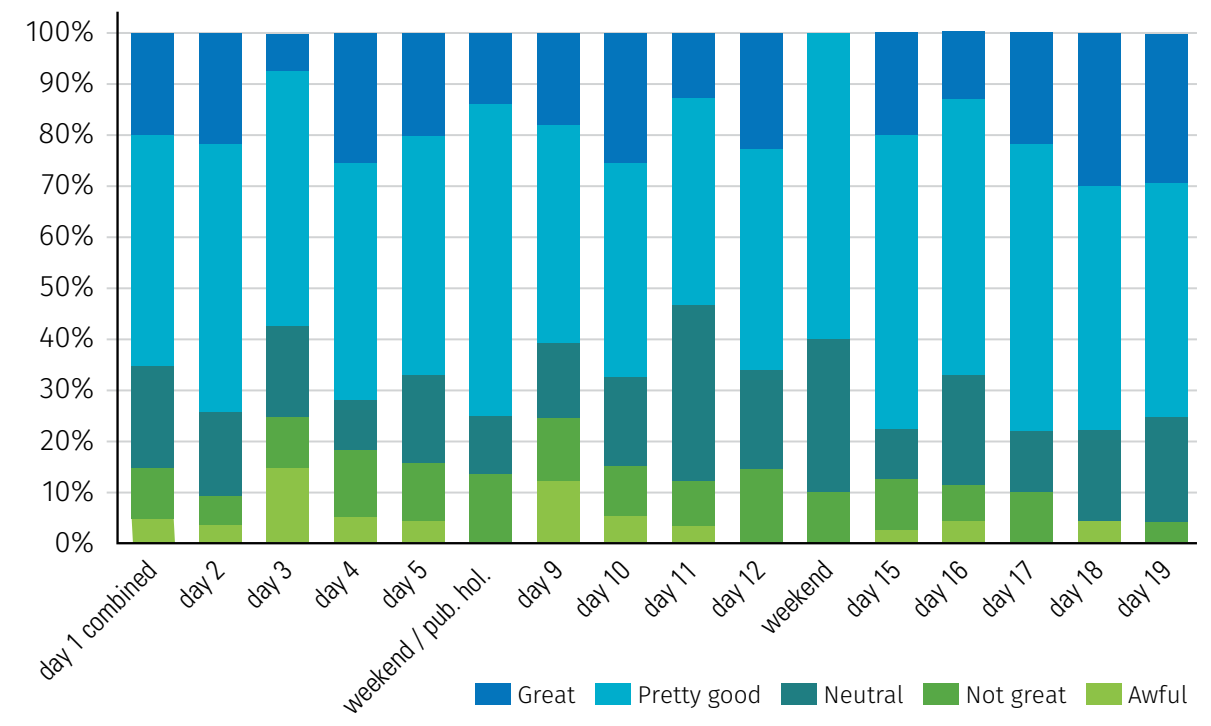

Figure 2: Daily morale-o-meter trial results

Note: 'day 1 combined' is the combination of results from 27 May and includes two additional early submissions from the day before. Entries have been combined on weekends (including the public holiday) due to reduced staffing.

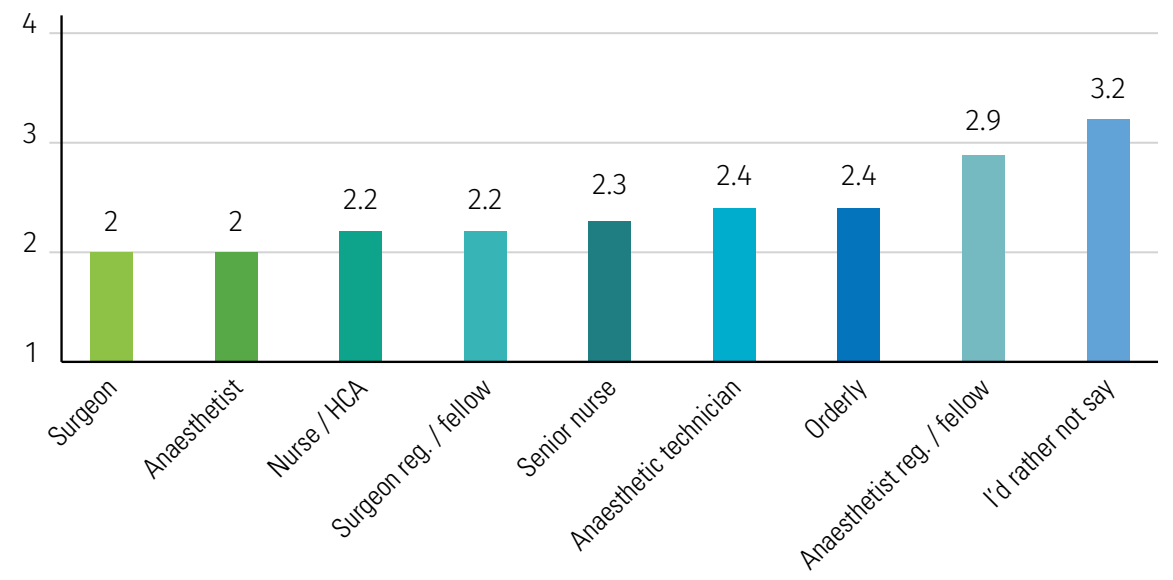

Figure 3: Job satisfaction averages by job role over trial period

Note: mean score scale: 1 = great, 2 = pretty good, $3=$ neutral, $4=$ not great, $5=$ awful

significant difference in overall job satisfaction found between overall mean scores of those who identified as a senior nurse or nurse (2.2 and 2.3, respectively).

Analyses of factors that influenced job satisfaction responses found that positive responses (i.e. 1 or 2 ) were most commonly influenced by 'relationships and communication with colleagues' (34\% and 39\%), closely followed by 'the nature of the clinical work' (29\% and 28\%). Negative responses (i.e. 4 or 5 ) were most frequently influenced by 'organisational factors' (33\% and $33 \%$ ), very closely followed by 'relationships and communication with colleagues' (33\% and 29\%). Results for OR nurses followed a similar trend, with 'relationships and communication with colleagues' chosen most frequently as the reasons for both a negative or positive day at work (see Table 3).

\section{Staff feedback}

The feedback survey was completed by 38 trial participants ( $14 \%$ response rate). Job roles comprised 47 per cent nurses, 13 per cent anaesthetic technicians, 11 per cent anaesthetists, 8 per cent orderlies and 3 per cent surgeons, with 18 per cent not identified. Sixty-one per cent of respondents reported that they thought it was either a 'good' or 'very good' idea to permanently implement a tool such as this, 34 per cent were 'not sure' and 5 per cent thought that it was a 'bad idea'; no respondents reported that it was a 'very bad' idea. The operating theatre was most commonly identified as the preferred location for the iPads (54\%), followed by the tearoom $(31 \%)$, anaesthetic technician room $(11 \%)$ and cell phone (4\%). The most commonly reported barriers to using the tool were 'forgetting to use the tool' (36\%) and 'being too busy' (31\%), followed by 'being too tired' (13\%) and 'the iPads not working properly' (11\%). Two per cent said they didn't feel comfortable answering the question and 18 per cent reported that they found no barriers to using the tool.

Four themes were identified from the qualitative comments on the survey:

1. positive feelings about the tool (e.g. 'It was good. Very easy and quick to fill in.')

2. questioning the tool's accuracy (e.g. 'I saw people fill it in when they were cheesed off about something but not when they were happy.')

3. concern about how the results from the tool would lead to actual change (e.g. 'Not sure if it's actually going to improve morale or make anything happen but if it gives it a chance to improve, I will do it.')

4. preference for the tool being available for short periods (e.g. 'I'd be more inclined to make an effort for a short period of time'). 
Table 3: Factors influencing job satisfaction responses for OR nurses

\begin{tabular}{|c|c|c|c|c|c|c|c|}
\hline $\begin{array}{l}\text { Response option } \\
\text { ( } n=\text { no. of nurse } \\
\text { responses) }\end{array}$ & 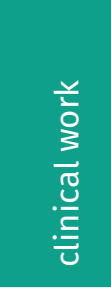 & 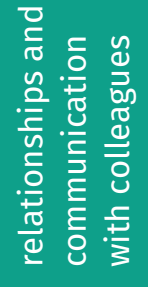 & 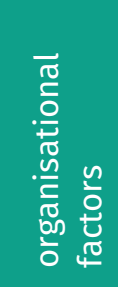 & 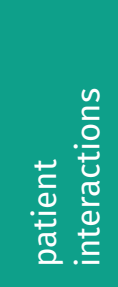 & 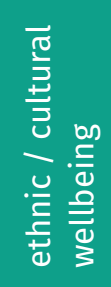 & 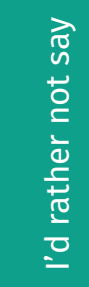 & 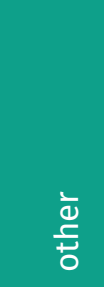 \\
\hline $\begin{array}{l}\text { Great } \\
(n=67)\end{array}$ & $\begin{array}{c}27 \% \\
f=46\end{array}$ & $\begin{array}{c}33 \% \\
f=58\end{array}$ & $\begin{array}{c}17 \% \\
f=30\end{array}$ & $\begin{array}{c}14 \% \\
f=25\end{array}$ & $\begin{array}{c}4 \% \\
f=7\end{array}$ & $\begin{array}{c}2 \% \\
f=3\end{array}$ & $\begin{array}{c}3 \% \\
f=5\end{array}$ \\
\hline $\begin{array}{l}\text { Pretty good } \\
(n=166)\end{array}$ & $\begin{array}{c}28 \% \\
f=94\end{array}$ & $\begin{array}{c}38 \% \\
f=127\end{array}$ & $\begin{array}{c}20 \% \\
f=66\end{array}$ & $\begin{array}{c}8 \% \\
f=27\end{array}$ & $\begin{array}{c}2 \% \\
f=7\end{array}$ & $\begin{array}{c}1 \% \\
f=2\end{array}$ & $\begin{array}{c}3 \% \\
f=11\end{array}$ \\
\hline $\begin{array}{l}\text { Neutral } \\
(n=62)\end{array}$ & $\begin{array}{c}23 \% \\
f=21\end{array}$ & $\begin{array}{c}19 \% \\
f=18\end{array}$ & $\begin{array}{c}35 \% \\
f=32\end{array}$ & $\begin{array}{c}2 \% \\
f=2\end{array}$ & $\begin{array}{c}2 \% \\
f=2\end{array}$ & $\begin{array}{c}8 \% \\
f=7\end{array}$ & $\begin{array}{c}11 \% \\
f=10\end{array}$ \\
\hline $\begin{array}{l}\text { Not great } \\
(n=33)\end{array}$ & $\begin{array}{l}10 \% \\
f=4\end{array}$ & $\begin{array}{c}37 \% \\
f=15\end{array}$ & $\begin{array}{c}30 \% \\
f=12\end{array}$ & $f=0$ & $f=0$ & $\begin{array}{c}8 \% \\
f=3\end{array}$ & $\begin{array}{l}15 \% \\
f=6\end{array}$ \\
\hline $\begin{array}{l}\text { Awful } \\
(n=9)\end{array}$ & $\begin{array}{c}8 \% \\
f=1\end{array}$ & $\begin{array}{l}50 \% \\
f=6\end{array}$ & $\begin{array}{l}34 \% \\
f=4\end{array}$ & $f=0$ & $f=0$ & $f=0$ & $\begin{array}{c}8 \% \\
f=1\end{array}$ \\
\hline
\end{tabular}

*Note. $n=$ number of responses from OR nurses over the three-week period.

$f=$ frequency of selection over the three-week period (participants could make multiple selections). For example, ' $n=67$ ' under 'great' indicates that 'great' was chosen 67 times by participants; ' $f=46$ ' under 'nature of the clinical work' indicates that this option was chosen 46 times during the trial when participants chose 'great'.

\section{Tool validity}

Matching the daily survey and the validation survey via participantcreated username led to a final sample of 31 participants being included in the validity analyses. The mean number of entries per participant in the validation survey was 4.3 (median 3, range 1-14). A significant relationship was found between daily job satisfaction and overall job satisfaction $(y=0.78, S E=$ 0.16, $p<0.01$ ) as well as a significant relationship between daily-level job satisfaction with emotional exhaustion ( $y=-0.51, S E=0.2, p<$ $0.01)$ and affective commitment ( $y=$ $0.77, S E=0.11, p<0.01$ ), demonstrating the convergent and predictive validity of the single-item job satisfaction measure in this study.

\section{Discussion}

This study explored a number of factors relating to the value, validity and viability of implementing a daily job satisfaction measurement tool within the OR setting. The overall results from the trial were positive: staff from a wide range of job roles participated in the trial, with nurses making up the largest group. The majority of staff that completed the feedback survey indicated that they thought the tool was a good idea. Aspects of the tool, for example the short length of time required to complete and flexibility in when and where it could be used, appeared to support staff engagement. Many survey respondents identified having the iPads in the theatres as their preferred location. Given that different staff members have varying periods of downtime within the OR, having the iPads in the theatres allowed them to complete the tool during work hours.

The findings also provide initial support for the convergent validity of daily job satisfaction with overall satisfaction, and the predictive validity of daily job satisfaction with both affective commitment and emotional exhaustion (key components of organisational commitment and burnout). The significant relationship between daily job satisfaction and overall job satisfaction provides some reassurance that the tool is indeed measuring what it was intended to measure despite being modified for our purpose, suggesting that the average of daily results can be interpreted as an overall satisfaction score. One of the few studies that has explored this relationship previously was conducted by Ilies and Judge ${ }^{34}$ within an administrative setting. They used ecological 
momentary assessment methods three times per day for two weeks $(n=33)$ and similarly found a significant result demonstrating convergent validity between daily job satisfaction and overall satisfaction outcomes. Our significant predictive validity findings are consistent with a recent Canadian study conducted by Lee, MacPhee and Dahinten ${ }^{12}$. They also found a negative relationship between emotional exhaustion and job satisfaction for perioperative nurses ( $n=133$ ). Our results suggest that the tool can assist in predicting an increase or decline in the risk of burnout and the level of organisational commitment of employees. The validity of our tool results was further increased by the existence of an anonymous username. This feature provides the ability to distinguish between entries, permitting accurate calculations of the response rate, reducing sampling bias and allowing for time series analysis.

Overall, the job satisfaction results from the cohort in the study found that the majority of OR employees generally felt positive about their job during the trial period. Managers could easily identify the number of 'happy' or 'unhappy' staff on any given day, consider the percentage of the workforce participants represented, and identify what factors may influence responses from either the perspective of a particular job role or for the whole team. This allows for the development of timely and targeted interventions. For example, in our study, relationships and communication with colleagues were major factors influencing both a positive and negative day at work for nurses. This is in keeping with Lee, MacPhee and Dahinten ${ }^{12}$ who identified the nurse-physician relationship as a significant predictor of perioperative nurse job satisfaction. In our study, the importance of relationships and communication with colleagues was also clear for the wider workforce, suggesting this would be a logical starting point for any intervention that aims to improve team staff satisfaction outcomes for this cohort.

Our study also identified some key areas that need to be addressed prior to further trialling or implementing the tool. Firstly, while the overall response rate was high, the daily response rate was only 21 per cent and a large number of staff members used the tool only once or twice over the trial period. Many reported that they forgot to use the tool or felt too busy to engage with it. This suggests that a reminder system is required, ideally embedded within daily routine alongside other daily expectations such as surgical briefings and checklists.

Survey feedback from staff suggested that while many were interested in initiatives that would improve overall morale, they questioned how the data would be used and if it would indeed lead to an improvement in job satisfaction. Transparent and regular feedback and action from managers are likely to be essential for the tool's success, with trust likely to develop as staff see evidence of positive change through its use. This was a seen in both the Frampton et al. ${ }^{18}$ and Hinsley et al.7 studies, which were conducted over much longer time frames. Both studies reported an increase in staff engagement as management actively and positively responded to feedback and comments.

Lastly, caution is needed comparing job roles and specialities, as understandably those that were most negative about how they were feeling in their jobs were also less likely to identify their job role or speciality. Feeling comfortable sharing this information is likely to improve as trust is developed over time.

A number of comparisons can be made between our study and those of Frampton et al.18 and Hinsley et al. ${ }^{17}$ As with our study, both studies developed the tool in collaboration with hospital personnel. Both studies used a simple visual system, smiley face and traffic light, and aimed to gain additional information regarding the reasons underpinning staff responses. While the tools from these two studies share a number of similarities with the morale-ometer, neither study appeared to use pre-validated questions, there were no mechanisms to trace individual entries, and there was minimal consideration of the validity of the results. While this may be sufficient if data were solely used informally at a local level, managers wanting to analyse the data as an additional key performance indicator to influence decision-making and policy need to know the validity of the data.

\section{Limitations}

This study was conducted in one hospital with one sample over a relatively short time period, limiting any generalisation of the findings to other populations. In addition, the low response rate at a daily level as well as for the feedback and validation survey may have resulted in some sampling bias. A further possible limitation relates to the power of the analysis of the data via multi-level modelling. Although no research to date has investigated the appropriate sample size for this analysis, it is generally accepted that the number of level-2 units (participants, in this study) is of particular importance ${ }^{35}$. In this study 31 participants were included in the validity analyses by matching the daily survey and the validation survey. When the number of level-2 units is fewer than 50, the standard 
errors for the fixed parameters are slightly biased downward ${ }^{36}$. Lastly, any study that requires self-reporting comes with the risk of common method bias ${ }^{13}$.

\section{Implications for perioperative nursing}

Daily measurement of job satisfaction has the potential to be a highly effective tool for nurse managers at all levels in the OR, enabling up-to-date and valid information which can be tracked and monitored over time. The close nature of the OR team means that job satisfaction is often inter-related between team members and decisions impacting one profession will likely impact on another ${ }^{26}$. Consequently, assessing and meeting the needs of nurses in this setting should not be done in isolation. The morale-o-meter tool allows job satisfaction to be viewed and managed from an interprofessional perspective, building and strengthening healthy inter-professional relations. It also provides the opportunity to give a measure for a team which could be a particular professional group, an individual theatre team, a surgical speciality or the entire theatre team. As the tool is further established, there is potential to monitor for variance and trends over time, and to explore its sensitivity to other theatre metrics (e.g. changes in theatre utilisation, theatre policy or staff changes).

\section{Conclusion}

Overall, the results of the moraleo-meter study provide meaningful evidence supporting the validity and viability of using a daily single-item job satisfaction measure in the OR setting. This tool has the potential to change the way job satisfaction is measured and managed in the OR setting, improving job satisfaction outcomes and enhancing outcome measures for staff wellbeing initiatives. Further research is recommended to be conducted across multiple sites for longer periods of time.

\section{Funding}

This research received no specific grant from any funding agency in the public, commercial or not-for-profit sectors. The University of Auckland Doctoral Scholarship fund was received as part of doctoral study.

\section{Acknowledgments}

The authors would like to thank and acknowledge all hospital personnel that contributed and participated in this study.

\section{Ethical statement}

This project was approved by the Human Participants Ethics Committee at the University of Auckland, reference number 022098.

\section{Conflict of interest}

No conflict of interest has been declared by the authors.

\section{References}

1. Kutney-Lee A, McHugh MD, Sloane DM, Cimiotti JP, Flynn L, Neff DF et al. Nursing: A key to patient satisfaction. Health Aff (Millwood) 2009;28(4):w669-677.

2. Linzer M, Poplau S, Brown R, Grossman E, Varkey A, Yale S et al. Do work condition interventions affect quality and errors in primary care? Results from the healthy work place study. J Gen Intern Med 2017;32(1):56-61.

3. MacHe S, Vitzthum K, Klapp BF, Groneberg DA. Improving quality of medical treatment and care: Are surgeons' working conditions and job satisfaction associated to patient satisfaction? Langenbeck's Arch Surg 2012;397(6):973-982.

4. Shanafelt TD, Balch CM, Bechamps GJ, Russell T, Dyrbye L, Satele D et al. Burnout and career satisfaction among American surgeons. Ann Surg 2009;250(3):463-470.
5. Williams ES, Manwell LB, Konrad TR, Linzer $M$. The relationship of organizational culture, stress, satisfaction, and burnout with physician-reported error and suboptimal patient care: Results from the MEMO study. Health Care Manage Rev 2007;32(3):203-212

6. Makary MA, Sexton JB, Freischlag JA, Holzmueller CG, Millman EA, Rowen L et al. Operating room teamwork among physicians and nurses: Teamwork in the eye of the beholder. J Am Coll Surg 2006;202(5):746-752.

7. Ahmad A, Rainyee RA. Which is the better predictor of employee turnover intentions: Job satisfaction or organizational commitment? A literature review. Int J Information Bus Manag 2014;6(1):2-10.

8. Lu H, Zhao Y, While A. Job satisfaction among hospital nurses: A literature review. Int J Nurs Stud;94:21-31.

9. Albion M, Fogarty GJ, Machin MA, Patrick J. Predicting absenteeism and turnover intentions in the health professions. Aust Heal Rev 2008;32(2):271-281.

10. World Health Organization (WHO). Working Together for Health: World Health Report 2006. Vol 19. Geneva: WHO; 2006.

11. Oh HC, Phua TB, Tong SC, Lim JFY. Assessing the performance of operating rooms: What to measure and why? Proc Singapore Healthc 2011;20(2):105-109.

12. Lee SE, MacPhee M, Dahinten VS. Factors related to perioperative nurses' job satisfaction and intention to leave. Japan J Nurs Sci 2020;17(1):e12263.

13. Denscombe $M$. The good research guide : For small-scale projects. $5^{\text {th }}$ ed. Maidenhead, Berkshire: Open University Press; 2014.

14. Khan A, Hussain R, Plummer D, Minichiello $\mathrm{V}$. Too many surveys! Eliciting the views of general practitioners for not participating in postal surveys. Aust J Prim Health 2004;10:76-81.

15. Welbourne TM. The potential of pulse surveys: Transforming surveys into leadership tools. Employ Relat Today 2016;43:33-39.

16. Stevenson M. Measuring employee experience: How the pulse survey is an indicator of company health [Internet] Tampa, FL: HR Exchange Network; 2018 [cited 2020 April 8]. Available from: www.hrexchangenetwork.com/employeeengagement/articles/measuring-employeeexperience-how-the-pulse-survey.

17. Hinsley KE, Marshall AC, Hurtig MH, Thornton JM, O'Connell CA, Porter CL et al. Monitoring the health of the work environment with a daily assessment tool: The REAL - Relative Environment Assessment Lens - Indicator. Cardiol Young 2016;26(6):1082-1089. 
18. Frampton A, Fox F, Hollowood A Northstone K, Margelyte R, Smith-Clarke $S$ et al. Using real-time, anonymous staff feedback to improve staff experience and engagement. BMJ Qual Improv Reports 2017;6(1):U220946.w7041.

19. Spector P. Job Satisfaction: Application, Assessment, Causes, and Consequences. Melbourne: SAGE; 2014.

20. Judge TA, Weiss HM, Kammeyer-Mueller JD, Hulin CL. Job attitudes, job satisfaction, and job affect: A century of continuity and of change. J Appl Psychol 2017;102(3):356-374.

21. Wanous JP, Reichers AE, Hudy MJ. Overall job satisfaction: How good are single-item measures? J Appl Psychol 1997;82(2):247-252.

22. Dolbier CL, McCalister KT, Mallon MW, Steinhardt MA, Webster JA. Reliability and validity of a single-item measure of job satisfaction. Am J Heal Promot 2011;19(3):194-198.

23. Highhouse S, Becker AS. Facet measures and global job satisfaction. J Bus Psychol 1993;8(1):117-127.

24. Warr P, Cook J, Wall T. Scales for the measurement of some work attitudes and aspects of psychological well-being. J Occup Psychol 1979;52(2):129-148.
25. Kyriazos TA, Stalikas A. Applied psychometrics: The steps of scale development and standardization process. Psychology 2018;09(11):2531-2560.

26. James-Scotter M, Walker C, Jacobs S. An interprofessional perspective on job satisfaction in the operating room: A review of the literature. I Interprof Care 2019;33(6):782-794.

27. Haar JM, Brougham DM. An Indigenous model of career satisfaction: Exploring the role of workplace cultural wellbeing. Soc Indic Res 2013;110(3):873-890.

28. Yurek LA, Vasey J, Sullivan Havens D. The use of self-generated identification codes in longitudinal research. Eval Rev 2008;32(5):435-452.

29. Scarpello V, Campbell JP. Job satisfaction: Are all the parts there? Pers Psychol 1983;36(3):577-600.

30. Allen NJ, Meyer JP. The measurement and antecedents of affective, continuance and normative commitment to the organization. J Occup Psychol 1990;63(1):1-18.
31. Maslach C, Jackson SE, Leiter MP. Maslach Burnout Inventory. $3^{\text {rd }}$ ed. In: Zalaquett CP, Woods RJ (Eds.) Evaluating Stress: A Book of Resources. London: The Scarecrow Press;1997, pp. 191-218.

32. Muthén L, Muthén B. Mplus. $7^{\text {th }}$ ed. Los Angeles: Muthén \& Muthén; 2015.

33. Ohly S, Sonnentag S, Niessen C, Zapf D. Diary studies in organizational research: An introduction and some practical recommendations. J Pers Psychol 2010;9(2)79-93.

34. Ilies R, Judge TA. An experience-sampling measure of job satisfaction and its relationships with affectivity, mood at work, job beliefs, and general job satisfaction. Eur J Work Organ Psychol 2004;13(3):367-389.

35. Preacher KJ, Zyphur MJ, Zhang Z. A general multilevel SEM framework for assessing multilevel mediation. Psychol Methods 2010;15(3):209-233.

36. Hox JJ. Multilevel Analysis: Techniques and Applications. 2nd ed. Milton Park UK; Routledge/Taylor \& Francis Group; 2010. 